\title{
PENERAPAN KODE ETIK NOTARIS DALAM PEMBUATAN AKTA PEMBAGIAN WARIS NO 31 MENURUT UUJN NO 2 TAHUN 2014
}

\author{
Yoki Kurniawan \\ (Mahasiswa Program S1 Fakultas Hukum Universitas Tarumanagara) \\ (E-mail: Yokizz_Chenzz@yahoo.co.id)
}

\section{Hanafi Tanawijaya}

(Corresponding Author)

(Dosen Hukum Agraria Fakultas Hukum Universitas Tarumanagara, Meraih Gelar Sarjana dari

Fakultas Hukum Universitas Tarumanagara, Magister Hukum Dari Fakultas Hukum Universitas

Tarumanagara)

(E-mail: Hanafitanawijaya@gmail.com)

\begin{abstract}
Notary is a position or ordinary we call as general officials appointed by the State and work to serve the public interest. Not only that, a notary also in carrying out its duties and authority must comply fully with the prevailing laws and regulations in Indonesia. Each position certainly has an ethics in the profession which is called a code of ethics, as well as a notary who has a code of ethics in his profession. But out there masi no notaries who violate the code of ethics as mentioned in the law, In accordance with the title of the author of the adopted method of research used is the normative research method supported by interviews that are expected to help answer the problems of this study. The authors conducted interviews with the supervisory board, notaries, and legal experts. In this case the notary has been declared guilty by the Regional Supervisory Board (MPD) and will proceed the case to the level of sanction by the Regional Supervisory Board (MPW) and after receiving the sanction it will proceed to the next level of Central Assembly (MPP) to be sanctioned which has been granted by the level of the Regional Supervisory Board (MPW).
\end{abstract}

Keywords: notary, Code Of Ethics 


\section{PENDAHULUAN}

\section{A. Latar Belakang}

Hukum merupakan bagian yang tidak dapat dipisahkan dari kehidupan masyarakat manusia sehingga di dalam masyarakat selalu ada sistem hukum, ada masyarakat ada norma hukum (ubi societas ibi ius). Kehadiran hukum justu untuk menegakkan keseimbangan perlakuan antara hak perorangan ataupun hak bersama.. Oleh karena itu, secara hakiki hukum haruslah pasti dan seadil-adilnya sehingga dapat berfungsi sebagaimana mestinya. Negara Indonesia berdasarkan Pancasila dan Undang-Undang Dasar Negara Republik Indonesia 1945 merupakan Negara hukum, dimana hukum itu berperan penting bagi seluruh rakyatnya dikarenakan hukum yang bersifat memaksa dan wajib dipatuhi. Hukum ini sendiri merupakan suatu rangkaian peraturan-peraturan mengenai tingkah laku orang-orang sebagai masyarakat, sedangkan satu-satunya tujuan dari hukum ialah mengadakan keselamatan, kebahagiaan dan tata tertib didalam masyarakat.

Indonesia ini hukum sangat dijunjung tinggi, adapula peraturan-peraturan hukum yang dibuat untuk mengatur mengenai setiap hal yang boleh atau tidak untuk dilakukan didalam masyarakat. Terdapat pula berbagai macam profesi hukum yang ada di Indonesia yakni salah satunya yaitu profesi Jabatan Notaris. Dalam bidang tertentu tugas tersebut oleh pemerintah melalui Undang-Undang diberikan dan dipercayakan kepada Notaris dan sebaliknya masyarakat juga harus percaya bahwa Akta Notaris yang dibuat itu memberikan kepastian hukum bagi para masyarakatnya, sesuai dengan bunyi Pasal 15 Ayat 1 Undang-Undang nomor 2 Tahun 2014 tentang perubahan atas Undang-Undang nomor 30 Tahun 2004 tentang Jabatan Notaris.

Notaris dalam menjalankan tugas dalam jabatannya harus memiliki keterampilan dalam profesi bidang hukum juga harus dilandasi dengan tanggungjawab dan moral yang tinggi serta pelaksanaan terhadap tugas jabatannya maupun nilai-nilai etika di dalamnya, sehingga dapat menjalankan tugasnya sesuai dengan ketentuan hukum dan 
Undang-Undang yang berlaku. Pasal 1 Angka 1 Undang-Undang Nomor 2 Tahun 2014 tentang Perubahan Atas Undang-Undang Nomor 30 Tahun 2004 tentang Jabatan Notaris yang menyebutkan notaris adalah pejabat umum yang berwenang untuk membuat akta autentik dan memiliki kewenangan lainnya sebagaimana dimaksud dalam Undang-Undang ini atau berdasarkan Undang-Undang lainnya. ${ }^{1}$

Tugas pokok notaris ialah membuat akta otentik, baik yang ditentukan oleh peraturan perundang-undangan maupun oleh keinginan orang tertentu dan badan hukum yang memerlukannya. ${ }^{2}$ Akta otentik merupakan suatu bukti yang mengikat, dalam arti bahwa yang ditulis dalam akta tersebut harus dipercaya oleh Hakim, yaitu harus dianggap sebagai benar selama ketidakbenarannya tidak dibuktikan, dan memberikan suatu bukti yang sempurna, dalam arti ia sudah tidak memerlukan suatu penambahan pembuktian.Ia merupakan alat bukti yang mengikat dan sempurna. ${ }^{3}$ Pembuatan akta otentik yang diharuskan oleh peraturan perundang-undangan adalah dalam rangka menciptakan kepastian, ketertiban dan perlindungan hukum bagi masyarakat.

Dalam sebuah disertasi yang dibuat oleh seorang sarjana yang bernama C.A.Kraan dengan judul De Authentieke Akte (Gouda Quint BV 1984) dalam bagian pertama dikupas secara teliti, sistematis, serta tuntas seluk-beluk sebenarnya akta autentik di Negara Civil Law seperti dasar-dasarnya, ciri-cirinya, siapa yang berhak membuatnya, sebabnya diperlukan seorang pejabat umum untuk pekerjaan itu, wewenangnya, bentuk akta, penggunaannya dalam proses pembuktian, dan lain-lain. ${ }^{4}$

${ }^{1}$ Indonesia, Undang-Undang Nomor 2 Tahun 2014 tentang Perubahan Atas Undang-Undang Nomor 30 Tahun 2004 tentang Jabatan Notaris.

${ }^{2}$ Supriadi, Etika dan Tanggung Jawab Profesi Hukum di Indonesia,(Jakarta: Sinar Grafika, 2006), hal.37.

${ }^{3}$ R.Subekti, Hukum Pembuktian, (Jakarta:Pradnya Paramita, 1995), hal.27.

${ }^{4}$ Tan Thong Kie, Studi Notariat serba-serbi praktek notaris (Jakarta: PT Ichtiar Baru Van Hoeve, 2007), hal.245. 
Notaris dalam menjalankan jabatannya tidak hanya menjalankan pekerjaan yang diamatkan oleh Undang-Undang saja, namun Notaris harus bertanggung jawab untuk melaksanakan kepercayaan yang diberikan masyarakat umum yang dilayaninya. Seorang Notaris harus berpegang teguh kepada Kode Etik Notaris, namun pada realitasnya keselarasan pelaksanaan hukum dilapangan ini masih ada Notaris yang melakukan pelanggaran terhadap Kode Etik.

Etika profesi adalah sikap etis yang dituntut untuk dipenuhi oleh professional dalam mengemban profesinya. Pembuatan akta otentik ini haruslah tidak melanggar etika profesi yang dimiliki oleh notaris, sebagaimana yang di atur dalam Pasal 3 Perubahan Kode Etik Notaris Kongres Luar Biasa Ikatan Notaris Indonesia Banten, 29-30 Mei 2015 dalam menjalankan jabatannya notaris wajib:

a. Memiliki moral, akhlak serta kepribadian yang baik

b. Menghormati dan menjunjung tinggi harkat dan martaban Jabatan Notaris

c. Menjaga dan membela kehormatan perkumpulan

d. Berprilaku jujur, mandiri, tidak berpihak, amanah, seksama, penuh rasa tanggungjawab, berdasarkan peraturan perundang-undangan dan isi sumpah jabatan Notaris

e. Meningkatkan ilmu pengetahuan dan keahlian profesi yang telah dimiliki tidak terbatas pada ilmu pengetahuan hukum dan kenotariatan

f. Mengutamakan pengabdian kepada kepentingan masyarakat dan Negara

g. Memberikan jasa pembuatan akta dan kewenangan lainnya untuk masyarakat yang tidak mampu tanpa memungut honorarium

h. Menetapkan satu kantor di tempat kedudukan dan kantor tersebut merupakan satusatunya kantor bagi notaris yang bersangkutan dalam melaksanakan tugas jabatan sehari-hari

i. Memasang 1 (satu) papan nama di depan/di lingkungan kantornya dengan pilihan ukuran yaitu $100 \mathrm{~cm}$ x $40 \mathrm{~cm}, 60 \mathrm{~cm}$ atau $200 \mathrm{~cm}$ x $80 \mathrm{~cm}$, yang memuat

1. Nama lengkap dan gelar yang sah

2. Tanggal dan nomor surat keputusan pengangkatan yang terakhir sebagai notaris

3. Tempat kedudukan

4. Alamat kantor dan nomor telepon/fax

Dasar papan nama berwarna putih dengan huruf berwarna hitam dan tulisan di atas papan nama harus jelas dan mudah dibaca. Kecuali lingkungan kantor tersebut tidak dimungkinkan untuk pemasangan papan nama dimaksud. 
j. Hadir, mengikuti dan berpartisipasi aktif dalam kegiatan yang diselenggarakan oleh perkumpulan

k. Menghormati, mematuhi, melaksanakan peraturan-peraturan dan keputusankeputusan perkumpulan

1. Membayar uang iuran perkumpulan secara tertib

m. Membayar uang duka untuk membantu ahli waris teman sejawat yang meninggal dunia;

n. Melaksanakan dan mematuhi semua ketentuan tentang honorarium yang ditetapkan perkumpulan

o. Menjalankan jabatan notaris di kantornya, kecuali karena alasan-alasan tertentu

p. Menciptakan suasana kekeluargaan dan kebersamaan dalam melaksanakan tugas jabatan dan kegiatan sehari-hari serta saling memperlakukan rekan sejawat secara baik, saling menghormati, saling menghargai, saling membantu serta selalu berusaha menjalin komunikasi dan tali silaturahim

q. Memperlakukan setiap klien yang dating dengan baik, tidak membedakan status ekonomi dan/atau status sosialnya

r. Membuat akta dalam jumlah batas kewajaran untuk menjalankan peraturan perundang-undangan, khususnya Undang-Undang tentang Jabatan Notaris dan Kode Etik

Sanksi bagi notaris yang melakukan pelanggaran kode etik dalam pasal 6

Perubahan Kode Etik Notaris Kongres Luar Biasa Ikatan Notaris Indonesia Banten 29-30 Mei 2015 sebagai berikut:

1. Sanksi yang dikenakan terhadap anggota yang melakukan pelanggaran Kode Etik dapat berupa:
(a) Teguran
(b)Peringatan
(c) Pemberhentian sementara dari keanggotaan perkumpulan
(d)Pemberhentian dengan hormat dari keanggotaan
(e)Pemberhentian dengan tidak hormat dari keanggotaan

2. Penjatuhan sanksi sebagaimana terurai di atas terhadap anggota yang melanggar Kode Etik disesuaikan dengan kuantitas dan kualitas pelanggaran yang dilakukan anggota tersebut.

3. Dewan Kehormatan Pusat berwenang untuk memutuskan dan menjatuhkan sanksi terhadap pelanggaran yang dilakukan oleh anggota biasa (dari Notaris aktif) perkumpulan, terhadap pelanggaran norma susila atau perilaku yang merendahkan 
harkat dan martabat notaris, atau perbuatan yang dapat mengurangi kepercayaan masyarakat terhadap notaris.

4. Pelanggaran Kode Etik yang dilakukan oleh orang lain (yang sedang dalam menjalankan jabatan Notaris), dapat dijatuhkan sanksi teguran dan/atau peringatan.

5. Keputusan Dewan Kehormatan berupa teguran atau peringatan tidal dapat diajukan banding.

6. Keputusan Dewan Kehormatan Daerah/Dewan Kehormatan Wilayah berupa pemberhentian sementara atau pemberhentian dengan hormat atau pemberhentian dengan tidak hormat dari keanggotaan perkumpulan dapat diajukan banding ke Dewan Kehormatan Pusat.

7. Keputusan Dewan Kehormatan Pusat tingkat pertama berupa pemberhentian sementara atau pemberhentian dengan hormat atau pemberhentian dengan tidak hormat dari kenaggotaan perkumpulan dapat diajukan banding ke kongres.

8. Dewan Kehormatan Pusat berwenang pula untuk memberikan rekomendasi disertai usulan pemecatan sebagai notaris kepada Menteri Hukum dan Hak Asasi Manusia Republik Indonesia.

Sesuai dengan kewajiban notaris di atas kita tidak dapat menyangkal bahwa masih ada diluar sana notaris yang masih tidak menaati aturan seperti contoh didalam sebuah keluarga yang memiliki 8 orang anak, dimana saat kepala keluarga LDS meninggal dunia yang kemudian meninggalkan harta kepada 8 orang anaknya yang di buat dalam akta keterangan hak waris. Anak kedua LJH sedang berada diluar negeri dan ke-7 orang anak lainnya pergi ke notaris untuk membuat akta perjanjian pembagian warisan, notaris JS yang bertindak sebagai pembuat akta perjanjian harta warisan yang hanya mencantumkan 7 orang ahli waris dalam pembagian harta hasil penjualan rumah yang mana pada dasarnya didalam akta keterangan hak waris tertuliskan 8 orang ahli waris. 
Penelitian ini menjadi sangat menarik untuk dilakukan, karena didalam prakteknya masih terdapat notaris yang mengabaikan kewajiban atau wewenangnya sebagai pejabat publik yang berwenang membuat akta otentik tertentu.

Berdasarkan diatas tersebut notaris telah melanggar Pasal 3 huruf d Perubahan Kode Etik Notaris Kongres Luar Biasa Ikatan Notaris Indonesia Banten, 29-30 Mei 2015 Berprilaku jujur, mandiri, tidak berpihak, amanah, seksama, penuh rasa tanggung jawab, berdasarkan peraturan perundang-undangan dan isi sumpah jabatan notaris maka seorang notaris haruslah bertindak jujur dalam pembuatan akta dan surat-surat yang akan dibuatnya tersebut.

Maka berdasarkan latar belakang di atas maka penulis tertarik untuk membuat skripsi yang berjudul: "PENERAPAN KODE ETIK NOTARIS DALAM PEMBUATAN AKTA PEMBAGIAN HAK WARIS NO 31 MENURUT UUJN NO 2 TAHUN 2014".

\section{B. Permasalahan}

Berdasarkan uraian latar belakang di atas maka, diangkatlah rumusan masalah yaitu bagaimana penerapan kode etik notaris dalam pembuatan akta pembagian waris no 31 yang tidak mencantumkan secara lengkap nama-nama ahli waris dan akibat hukumnya?

\section{Metode Penelitian}

Penelitian hukum adalah suatu proses untuk menemukan aturan hukum, prinsip-prinsip hukum, maupun doktrin-doktrin hukum guna menjawab isu hukum yang dihadapi. ${ }^{5}$

\section{Jenis Penelitian}

Berdasarkan permasalahan yang diteliti oleh penulis, maka metode penelitian normatiflah yang digunakan oleh penulis. Metode penelitian hukum

\footnotetext{
${ }^{5}$ Peter Mahmud Marzuki, Penelitian Hukum, (Jakarta: Kencana, 2006), hal. 83
} 
normative atau metode penelitian hukum yang dilakukan dengan cara meneliti bahan pustaka yang ada. ${ }^{6}$ Penelitian normatif ini menggunakan data sekunder(data yang sudah ada) seperti Peraturan Perundang-undangan, Peraturan Kode Etik dan sebagainya.

Tahapan pertama penelitian hukum normative adalah penelitian yang dituukan untuk mendapatkan hukum obyektif(norma Hukum), yaitu dengan mengadapan penelitian terhadap masalah-masalah yang berkenaan dengan hukum. Tahapan kedua penelitian hukum normatif ini adalah penelitian yang dijukan untuk mendapatkan hukum subyektif(hak dan kewajiban)

\section{Sifat Penelitian}

Penelitian yang dilakukan bersifat deskriptif yaitu menggambarkan gejalagejala dilingkungan masyarakat terhadap suatu kasua yang merupakan tata cara penelitian yang dihadilkan data deskriptif. ${ }^{7}$ Penulis berharap untuk dapat lebih jauh meneliti serta memberikan data yang diteliti tentang objek yang diteliti ini adapun penulis ingin memberikan deskripsi mengenai proses penerapan hukum sebagaimana yang diatur didalam Undang-Undang.

\section{Sumber-Sumber Penelitian}

Penulis mengginakan metode penelitian hukum normatif. Penelitin hukum normative ini digunakan dengan cara mengumpulkan data-data yang sudah ada atau biasa disebut dengan data sekunder. Metode penelitian hukum normative ini, memiliki 3 macam bahan hukum yang akan dipergunakan penulis, yaitu:

a. Bahan Hukum Primer

Bahan hukum primer merupakan bahan hukum yang dapat mengikat atau dapat dikatakan bahan hukum yang dapat membuat orang taat pada hukum seperti Peraturan PerUndang-Undangan. Bahan hukum primer yang penulis gunakan didalam penulisan ini yakni: Undang-Undang Republik Indonesia

\footnotetext{
${ }^{6}$ Soerjono Soekanto dan Sri Mamudji,"Penelitian Hukum Normatif Suatu Tinjauan Singkat", Cetakan Ke-11.(Jakarta:PT Raja Grafindo Persada 2009), hal.13.

${ }^{7}$ Soerjono Soekanto,"Pengantar Penelitian Hukum", (jakarta:UI Press, 1986), hal.32.
} 
Nomor 2 tahun 2014 Tentang Perubahan Atas Undang-Undang Nomor 30 Tahun 2004 Tentang Jabatan Notaris, Perubahan Kode Etik Notaris Kongres Luar Biasa Ikatan Notaris Indonesia Banten, 29-30 Mei 2015.

b. Bahan Hukum Sekunder

Bahan hukum sekunder dapat diartikan sebagai bahan hukum yang tidak mengikat tetapi malah menjelaskan mengeai bahan hukum primer yang merupakan hasil olahan untuk pendapat atau pikiran para ahli atau pakar yang mempelajari suatu bidang tertetu secara khusus dan memberikan petunjuk ke arah mana peneliti akan mengarah.

c. Bahan Hukum Tersier

Bahan hukum tersier adalah bahan hukum yang mendukung bahan hukum primer dan bahan hukum sekunder dengan memberikan pemahaman pengertian atas bahan hukum lainnya. Penelitian hukum ini terdapat beberapa pendekatan, dengan pendekatan tersebut peneliti akan mendapatkan informasi dari berbagai aspek mengenai isu yang sedang dicoba untuk dicari jawabannya. Macam-macam pendekatan yang digunakan penelitian hukum adalah: ${ }^{8}$

1) Pendekatan Undang-Undang (Statue Approach)

2) Pendekatan Kasus (Case Approach)

3) Pendekatan Historis (Historical Approach)

4) Pendekatan komparatif (Comparatif Approach)

5) Pendekatan Konseptual (Conceptual Approach)

Penelitian yang dilakukan oleh penulis lebih ditunjukkan kepada pendekatan Undang-Undang dan pendekatan kasus. Pendekatan Undang-

\footnotetext{
${ }^{8}$ Peter Mahmud Marzuki, "Penelitian Hukum”,(Jakarta:Kencana Prenada Media Group, 2009), hal.93.
} 
Undang dilakukan dengan menelaah semua Undang-Undang dan regulasi yang bersangkut paut dengan isu hukum yang sedang ditangani. ${ }^{9}$

\section{Teknik Pengumpulan Bahan Hukum}

Dalam penelitian hukum ini, penulis menggunakan tektnik pengumpulan data yaitu dengan melakukan studi pustaka terhadap bahan-bahan hukum yang akan digunakan, baik itu bahan hukum primer, bahan hukum skunder, maupun bahan hukum tersier. Penulis tentunya mengumpulkan bahan tersebut dengan diteliti lebih lanjut dengan membaca maupun dengan wawancara langsung pihak yang bersangkutan.

\section{Teknik pengolahan Bahan Hukum}

Dalam pengolahan bahan hukum ini, setelah bahan hukum terkumpul maka penulis akan melakukan pengolahan bahan, agar komponen bahan hukum yang sudah terkumpul tersebut dapat tersusun secara sistematis, sehingga dapat memudahkan penulis dalam melakukan analisa terhadap bahan hukum yang sudah terkumpul.

Pengolahan data atau yang dapat disebut dengan klasifikasi data, yaitu melakukan klasifikasi terhadap data dan bahan hukum yang telah terkumpul ke dalam kelas-kelas dari gejala-gejala yang sama atau yang dianggap sama. ${ }^{10}$ Dalam hal ini pengolahan bahan dilakukan dengan cara melakukan seleksi data sekunder atau bahan hukum, kemudian melakukan klasifikasi menurut penggolongan bahan hukum dan menyusun data hasil penelitian tersebut secara sistematis, tentu saja hal tersebut dilakukan secara logis, artinya ada hubungan dan keterkaitan bahan hukum satu dengan bahan hukum lainnya untuk mendapatkan gambaran umum dari hasil penelitian. ${ }^{11}$

\section{Teknik Analisi Bahan Hukum}

\footnotetext{
${ }^{9}$ Ibid, hal.93.

10 Mukti Fajar ND dan Yulianto Achmad,"Dualisme Penelitian Hukum Normatif dan Empiris”, Cetakan Ke- 1. (Yogyakarta: Pustaka Belajar, 2010), hal. 180.

${ }^{11}$ Ibid., hal.181.
} 
Dalam teknik analisis bahan hukum ini merupakan suatu kegiatan dalam penilitian yang melakukan kajian terhadap bahan yang sudah terkumpul yang kemudian diolah sehingga menjadi sistematis. Teknik analisis bahan hukum yang digunakan dalam penelitian ini adalah metode analisis bahan hukum kualitatif yang mana dipergunakan untuk menganalisis dan menjelaskan hasil dari penelitian yang sudah ada dan kemudian disajikan secara kualitatif.

\section{PEMBAHASAN}

\section{A. Hasil Penelitian}

Kasus ini berawal dari adanya peristiwa hukum kematian Tuan LIM DARWIN SUADI dahulu bernama LIM BENG TJONG (selanjutnya disebut Pewaris I). Pewaris I telah meninggal dunia di Jakarta, pada tanggal 30 Maret 1988. Kemudian oleh para keluarga pewaris I didaftarkan kepada Kantor Catatan Sipil Wilayah Jakarta Barat, yang dibuktikan dengan dikeluarkannya Akta Kematian nomor 382 / JB / 1988 tertanggal 05 April 1988.

Keluarga pewaris menindaklanjuti pengeluaran akta kematian pewaris I dengan mendatangi Kantor Notaris DARSONO PURNOMOSIDI, S.H. (selanjutnya disebut Notaris I), untuk meminta dibuatkan Akta Keterangan Hak Waris. Anggota keluarga yang meminta adalah istri dari pewaris I yang bernama KWEE TJIE MOY. Pada tanggal 30 April 1992, Akta Keterangan Hak Waris dibuat di hadapan Notaris I, di bawah nomor 168. Dari akta keterangan hak waris tersebut ditetapkan, telah ditetapkan ahli waris sebagai berikut :

1. Kwee Tjie Moy (perempuan) bagian waris 121/216

2. Harry Lim dahulu bernama Lim Ping Hoa (laki-laki) bagian waris 4/216

3. Lim Jeuh Hwie (perempuan) bagian waris $13 / 216$ 
4. Lim Jueh Ching (perempuan) bagian waris $13 / 216$

5. Lim Yueh Chien (perempuan) bagian waris $13 / 216$

6. Lim Ping Hsien (laki-laki) bagian waris 13/216

7. Lim Ping Liang (laki-laki) bagian waris $13 / 216$

8. Lim Jeuh Yien (perempuan) bagian waris $13 / 216$

9. Frendy Lim dahulu bernama Lim Ping Siung (laki-laki) bagian waris 13/216

Pada tanggal 17 April 2012, nyonya KWEE TJIE MOY (selanjutnya disebut Pewaris II) meninggal dunia di Jakarta, kemudian didaftarkan di Kepala Kantor Suku Dinas Kependudukan dan Pencatatan Sipil di Kota Administrasi Jakarta Selatan, kemudian oleh pendaftaran tersebut di keluarkannya Akta Kematian pada tanggal 03 Mei 2012 di bawah nomor 194/KMU/JS/2012. Kemudian oleh keluarga Pewaris II kembali ditindaklanjuti dengan mendatangi Notaris MUTIARA HARTANTO, S.H., untuk meminta dibuatkan Akta Keterangan Hak Waris pada tanggal 04 Juli 2012, di bawah nomor 04. Dari akta keterangan hak waris tersebut ditetapkan, telah ditetapkan ahli waris sebagai berikut :

1. Harry Lim dahulu bernama Lim Ping Hoa (laki-laki) bagian waris $1 / 8$

2. Lim Jeuh Hwie (perempuan) bagian waris $1 / 8$

3. Lim Jeuh Ching (perempuan) bagian waris $1 / 8$

4. Lim Yeuh Chien (perempuan) bagian waris $1 / 8$

5. Lim Ping Hsien (laki-laki) bagian waris $1 / 8$

6. Lim Ping Liang (laki-laki) bagian waris $1 / 8$ 
7. Lim Jeanny Rayinda Halim dahulu bernama Lim Jeuh Yien (perempuan) bagian waris $1 / 8$

8. Frendy Lim dahulu bernama Lim Ping Siung (laki-laki) bagian waris $1 / 8$

Setelah dibuatkan kedua akta keterangan hak waris, para ahli waris kecuali LIM JEUH HWIE datang dan menghadap ke Notaris JUDI SENTANA, S.H., M.H., untuk meminta dibuatkan akta Perjanjian antara pihak pertama yakni :

1. HARRY LIM dahulu bernama LIM PING HOA

\section{LIM JUEH CHING}

\section{LIM YUEH CHIEN}

\section{LIM PING HSIEN}

\section{LIM PING LIANG}

\section{LIM JEANNY RAYINDA HALIM dahulu bernama LIM JEUH YIEN}

Untuk membagi dan memisahkan hak milik para ahli waris kemudian untuk diberikan kepada pihak kedua yaitu FRENDY LIM dahulu bernama LIM PING SIUNG. Pemisahan dan pembagian tersebut, oleh pihak kedua diberikan ganti rugi sebesar Rp. 450.000.000,- (empat ratus lima puluh juta rupiah) kepada pihak pertama.

Permasalahn timbul dari pembuatan akta keterangan waris nomor 168 yang dibuat oleh Notaris Darsono Purnomosidi S.H di Jakarta, pada hari kamis tanggal 30 april 1992 dan akta keterangan hak waris nomor 04 yang dibuat oleh Mutiara Hartanto S.H di Jakarta pada tanggal 4 juli 2012, yang mana di dalam akta tersebut terdapat 8 (delapan) orang nama ahli waris, yaitu sebagai berikut: Harry Lim, Lim 
Jeuh Hwie, Lim Jueh Ching, Lim Yueh Chien, Lim Ping Hsien, Lim Ping Liang, Lim Jeuh Yien, Frendy Lim.

Permasalahan timbul setelah dibuatnya akta kuasa nomor 30 dan akta perjanjian nomor 31 yang dibuat oleh Judi Sentana S.H, M.H yang berwilayah di Jakarta Selatan, pada hari senin tanggal 26 november 2012 pada pukul 10.45 (sepuluh lewat empat puluh lima menit) Waktu Indonesi Barat. Pada akta perjanjian nomor 31 tersebut hanya mencantumkan 7 (tujuh) orang nama ahli waris yang mana seharusnya ada 8 (delapan) orang nama ahli waris yang sah menurut akta keterangan waris nomor 168 yang dibuat oleh Notaris Darsono Purnomosidi S.H dan akta keterangan hak waris nomor 04 yang dibuat oleh Notaris Mutiara Hartanto S.H.

Lim Jeuh Hwie (pelapor) yang beralamat di Jalan Alam Permai IX/PC 16 nomor 36 Pondok Pinang Jakarta Selatan selanjutnya melaporkan Notaris Judi Sentana S.H, M.H yang berlamat di Komplek Rukan Permata Senayan Blok C-45 Jalan Tentara Pelajar Senayan Jakarta Selatan kepada pihak yang berwenang yaitu Majelis Pengawas Daerah (MPD).

Ketika dalam pembuatan akta hak waris semua ahli waris seharusnya semua ahli waris harus hadir, dan manakala bila salah satu ahli warisnya tidak hadir misalnya ada 5 ahli waris kandung dan salah satunya sedang berada di luar negeri contoh amerika sedangkan 4 orang ahli waris lainnya pergi menghadap ke notaris, apakah akta tersebut batal? Tetap biasa dilaksanakan tapi yang tanda tangan hanya 4 orang ahli waris yang hadir saja dan 1 orang yang berada diluar negeri tersebut nama nya tetap harus ditulis didalam akta tersebut oleh notaris akan tetapi ahli waris yang berada diluar negeri ini tidak perlu menandatangani akta meskipun dia tidak memakai kuasa.

Ketika dia pulang ke Indonesia maka dia dapat membaca akta tersebut dan di dalam akta tersebut hak nya tidak akan hilang missal dalam pembagian warisan dan juga dalam pembuatan akta warisan tersebut juga harus ada data-data yang diperlukan seperti kartu keluarga contohnya sesuai dengan peraturan perundang-undangan yang 
berlaku, bilamana ahli waris yang berada di luar negeri tersebut kembali ke Indonesia dan ingin menandatangani akta tersebut tetap tidak bias dikarenakan penandatangan akta tersebut hanya bias dilakukan disaat menghadap dalam pembuatan akta tersebut, misalnya di bersi keras ingin menandatangani akta tersebut tetap tidak bias dikarena memang dia tidak hadir saat pembuatan akta tersebut, tandatangan tetap tidak boleh menyusul dan hanya dilakukan saat berhadapan dengan notaris.

Akta yang sudah dibuat wajib dibacakan di hadapan para ahli waris, bagaimana jika notaris tidak membacakan? Boleh saja, asalkan ahli waris lainnya membacakan akta tersebut akan tetapi notaris tetap harus menjelaskan hukumnya dan setelah semuanya menyetujui maka akta tersebut ditandatangani oleh notaris, kedua saksi, dan ahli waris yang hadir. bagaimana bila dalam pembuatan akta waris tersebut namun sang notaris tidak mencantumkan nama dari 5 orang anak kandung missal hanya mencantumkan nama 4 orang ahli waris saja, hal tersetbut tentu tidak boleh dilakukan dan bila dilakukan maka notaris yang bersangkutan dapat dilaporkan ke majelis pengawas daerah (MPD) untuk di panggil apakah benar notaris bersangkutan melakukan hal yang bersangkutan dan bila benar notaris tersebut melakukan pelanggaran tersebut.

maka pihak dari majelis pengawas daerah (MPD) ini akan menyatakan notaris tersebut bersalah dan akan memberikan rekomendasi kepada majelis pengawas wilayah (MPW) bahwa notaris yang bersangkutan tersebut telah melakukan pelanggaran jabatan karena seharusnya dia mengetahui ahli waris yang tertera ada 5 orang dan kenapa hanya ditulis 4 orang saja, dan bila salah satu dari ahli waris terebut melapor ke majelis pengawas daerah(MPD) maka akan ditindak lanjuti dan untuk sanksinya dapat dilihat di UUJN. ${ }^{12}$

Bilamana ahli waris yang namanya tidak disebutkan dalam akta hak waris tersebut melaporkan notaris secara pribadi karena pelanggaran kode etik dan baik kedua pihak akan di panggil untuk disidang baik itu notaris yang bersalah tersebut

\footnotetext{
${ }^{12}$ Hasil wawancara
} 
ataupun pihak ahli waris pelapor karena memang menurut majelis pengawas daerah (MPD) harus di panggil dikarenakan memang bukti dari pihak pelapor untuk akteakte keterangan tersebut lengkap, secara pidana mingkin dia ada konflik dengan salah satu ahli waris lainnya dia dapat melaporkan ke polisi hanya saja bila polisi ingin memanggil notaris yang bersangkutan harus melalui majelis kehormatan notaris (MKN). Untuk alasan segenap atau para ahli waris itu tidak diaturan mengenai segenap atau para ahli waris.

Dalam membuat suatu akta keterangan hak waris, segenap ahli waris harus hadir di hadapan notaris, untuk menunjukan data pribadinya masing-masing. Terdapat perbedaan antara kata-kata "Segenap ahli waris" \& "para ahli waris". "Para ahli waris" berarti ahli waris yang telah berada di hadapan notaris, sedangkan "Segenap ahli waris" dapat diartikan semua ahli waris dan tidak ada yang tertinggal. ${ }^{13}$

Seorang notaris dalam melaksanakan tugas dan wewenangnya membuat suatu akta keterangan hak waris, harus terlebih dahulu memeriksa apakah pewaris telah meninggalkan surat wasiat atau tidak. prosedur pemeriksaan ini dilakukan dengan pengajuan permohonan pengecekan kepada Balai Harta Peninggalan.

Batasan-batasan "jujur" dalam membuat suatu akta memiliki arti formiil, artinya kebenaran atas suatu kenyataan terbatas pada hal-hal yang telah diketahui oleh notaris berdasarkan dokumen dari diberikan dan ditunjukkan oleh klien. Berdasarkan Surat Edaran tanggal 20 Desember 1969 No. DPT/12/63/12/69 yang diterbitkan oleh Direktorat Agraria Direktorat Pendaftaran Tanah (Kadaster) di Jakarta, notaris diberikan wewenang untuk membuat akta keterangan hak waris (verklaring van erfrecht) untuk penduduk golongan keturunan Eropa dan golongan Tionghoa.

Dalam kasus yang sedang dibahas, notaris Judi Sentana, dapat dikatakan telah memenuhi unsur - unsur dari tindak pidana penggelapan. Notaris terkait telah mengetahui isi dari materiil dari aktanya tidak sesuai dengan keadaan nyata sehingga

\footnotetext{
${ }^{13}$ Hasil wawancara
} 
ada unsur kesengajaan dan secara melawan hukum memiliki barang sesuatu yang seluruhnya atau sebagian adalah kepunyaan orang lain, tetapi yang ada dalam kekuasaannya bukan karena kejahatan.

Dalam membuat suatu akta notariil, diperlukan beberapa persyaratan dokumen yang berkaitan dengan isi dari akta yang akan dibuat, seperti dokumen mengenai identitas, alas hak dan dokumen - dokumen lain yang dibutuhkan. Dokumen yang diperlukan dalam pembuatan suatu akta keterangan hak waris adalah dokumen yang berisikan mengenai identitas dan kronologis kependudukan, seperti Kartu Tanda Penduduk, Kartu Keluarga, Akta Perkawinan, Akta Kelahiran, Akta Kematian, dan surat - surat lain yang berkaitan. ${ }^{14}$

\section{B. Analisis}

1. Pelaksanaan penerapan kode etik terhadap notaris yang tidak memasukkan nama ahli waris yang sah dalam akta hak waris

Menurut Sudikno Mertokusumo akta adalah surat yang diberi tanda tangan, yang memuat peristiwa-peristiwa hukum, yang menjadi dasar dari suatu hak atau perikatan, yang dibuay sejak semula secara sengaja untuk tujuan pembuktian. ${ }^{15}$ Ada tiga landasan filosofis penyusunan akta autentik sebagaimana yang tercantum dalam Undang-Undang Nomor 2 Tahun 2014 tentang Perubahan atas Undang-Undang Nomor 30 Tahun 2004 tentang Jabatan Notaris yang meliputi: ${ }^{16}$

a) Menjamin kepastian hukum;

b) Menjamin ketetiban; dan

c) Perlindungan hukum bagi setiap warga Negara

\footnotetext{
${ }^{14}$ Hasil wawancara

${ }_{15}^{15}$ Daeng Naja, Teknik Pembuatan Akta, (Yogyakarta: Pustaka Yustisia, 2012), hal.1.

${ }^{16}$ H, Salim HS, Teknik Pembuatan Akta Satu, Cetakan Pertama (Jakarta: Raja Grafindo Persada, 2015), hal.14.
} 
Notaris merupakan pejabat umum yang berwenang untuk membuat akta otentik, yang mana akta otentik yang dibuatnya tidak dikhususkan untuk pejabat umum lainnya, sebagaimana yang dimaksudkan dalam Pasal 1 angka 1 Undang-Undang Nomor 2 Tahun 2014 tentang Jabatan Notaris (UUJN), yang mana berbunyi: "Notaris adalah pejabat umum yang berwenang untuk membuat akta otentik dan memiliki kewenangan lainnya sebagaimana dimaksud dalam Undang-Undang ini atau berdasarkan Undang- Undang lainnya”. Sebagai pejabat umum, notaris harus: (a) berjiwa pancasila; (b) taat kepada hukum, sumpah jabatan Kode Etik Notaris; (c) berbahasa Indonesia yang baik. ${ }^{17}$

Adapun tugas dan wewenang notaris yang diberikan kewenangan dan tugas-tugas oleh Undang-Undang Jabatan Notaris berdasarkan pada Pasal 15 Ayat (1) UndangUndang Nomor 2 Tahun 2014 tentang Perubahan Atas Undang-Undang Nomor 30 Tahun 2004 tentang Jabatan Notaris wewenang notaris yang utama adalah membuat akta otentik, yaitu mengenai semua perbuatan, perjanjian dan ketetapan yang diharuskan oleh peraturan perundang-undangan dan yang dikehendaki oleh yang berkepentingan atau para pihak atau penghadap hanya dapat dituangkan ke dalam akta yang dibuat di hadapan notaris atau akta pihak dan akta yang dibuat oleh notaris.

Menurut Pasal 1868 KUH Perdata yang dimaksud ialah suatu akta yang di dalam bentuk menurut ketentuan Undang-Undang dibuat oleh atau di hadapan pejabat umum yang berwenang untuk itu di tempat di mana akta itu dibuat. Dari pengertian akta otentik yang diuraikan dalam Pasal 1868 KUH Perdata, maka untuk suatu akta otentik harus memenuhi persyaratan-persyaratan berikut:

1. Akta itu harus dibuat oleh atau di hadapan seorang pejabat umum,

2. Akta itu harus dibuat dalam bentuk yang ditentukan oleh undang-undang,

3. Pejabat umum oleh atau di hadapan siapa akta itu dibuat, harus mempunyai wewenang untuk membuat akta itu.

\footnotetext{
${ }^{17}$ Abdulkadir Muhammad, Etika Profesi Hukum, cetakan ke-3, (Bandung: PT Citra Aditya Bakti, 2006), hal.89.
} 
Selain kewenangan membuat akta otentik sebagaimana telah dijabarkan diatas, kewenangan lainnya terdapat juga dalam Pasal 15 Ayat (2) Undang-Undang Jabatan Notaris antara lain:

a. Mengesahkan tanda tangan dan menetapkan kepastian tanggalsurat dibawah tangan dengan mendaftar dalam buku khusus;

b. Membukukan surat di bawah tangan dengan mendaftar dalam buku khusus;

c. Membuat kopi dari asli surat di bawah tangan berupa salinan yang memuat uraian sebagaimana ditulis dan digambarkan dalam surat yang bersangkutan;

d. Melakukan pengesahan kecocokan fotokopi dengan surat aslinya;

e. Memberikan penyuluhan hukum sehubungan dengan pembuatan akta;

f. Membuat akta yang berkaitan dengan pertanahan; atau Membuat akta risalah lelang.

Notaris dalam mejalankan jabatannya selain memiliki wewenang utama untuk membuat akta otentik, juga mempunyai kewajiban lainnya, yaitu Sesuai dengan Pasal 16 Ayat (1) Undang-Undang Jabatan Notaris dalam menjalankan jabatannya, notaris wajib:

a. bertindak amanah, jujur, saksama, mandiri, tidak berpihak, dan menjaga kepentingan pihak yang terkait dalam perbuatan hukum;

b. membuat Akta dalam bentuk Minuta Akta dan menyimpannya sebagai bagian dari Protokol Notaris;

c. melekatkan surat dan dokumen serta sidik jari penghadap pada Minuta Akta;

d. mengeluarkan Grosse Akta, Salinan Akta, atau Kutipan Akta berdasarkan Minuta Akta;

e. memberikan pelayanan sesuai dengan ketentuan dalam Undang-Undang ini, kecuali ada alasan untuk menolaknya;

f. merahasiakan segala sesuatu mengenai Akta yang dibuatnya dan segala keterangan yang diperoleh guna pembuatan Akta sesuai dengan sumpah/janji jabatan, kecuali undang-undang menentukan lain;

g. menjilid Akta yang dibuatnya dalam 1 (satu) bulan menjadi buku yang memuat tidak lebih dari 50 (lima puluh) Akta, dan jika jumlah Akta tidak dapat dimuat dalam satu buku, Akta tersebut dapat dijilid menjadi lebih dari satu buku, dan mencatat jumlah Minuta Akta, bulan, dan tahun pembuatannya pada sampul setiap buku;

h. membuat daftar dari Akta protes terhadap tidak dibayar atau tidak diterimanya surat berharga;

i. membuat daftar Akta yang berkenaan dengan wasiat menurut urutan waktu pembuatan Akta setiap bulan;

j. mengirimkan daftar Akta sebagaimana dimaksud dalam huruf $i$ atau daftar nihil yang berkenaan dengan wasiat ke pusat daftar wasiat pada kementerian yang 
menyelenggarakan urusan pemerintahan di bidang hukum dalam waktu 5 (lima) hari pada minggu pertama setiap bulan berikutnya;

k. mencatat dalam repertorium tanggal pengiriman daftar wasiat pada setiap akhir bulan;

1. mempunyai cap atau stempel yang memuat lambang negara Republik Indonesia dan pada ruang yang melingkarinya dituliskan nama, jabatan, dan tempat kedudukan yang bersangkutan;

m. membacakan Akta di hadapan penghadap dengan dihadiri oleh paling sedikit 2 (dua) orang saksi, atau 4 (empat) orang saksi khusus untuk pembuatan Akta wasiat di bawah tangan, dan ditandatangani pada saat itu juga oleh penghadap, saksi, dan Notaris; dan

n. menerima magang calon Notaris.

Dalam penelitian ini penulis lebih mendalami mengenai kewajiban dan wewenang notaris sebagaimana yang diatur didlam Pasal 16 Ayat 1 huruf a UndangUndang Jabatan Notaris Nomor 2 Tahun 2014, yang mana berbunyikan "bertindak amanah, jujur, saksama, mandiri, tidak berpihak, dan menjaga kepentingan pihak yang terkait dalam perbuatan hukum", disini sudah sangat jelas dituliskan bahwa notaris haruslah berntindak jujur, tidak berpihak dan lainnya dalam menjalankan jabatannya.

Berkaitan dengan kasus yang saya angkat dalam penelitian ini, suatu bentuk hasil penelitian yang telah saya analisis dan saya katakan adalah bahwa penerapakn kode etik didalam pembagian hak waris yang mana nama salah satu ahli waris yang sah tidak dicantumkan dalam akta tersebut adalah bahwa pada dasarnya Majelis Daerah (MPD) itu sendiri tidak berhak untuk menetukan bagaimana penerapan dari kode etik itu tersebut, tetapi bahwa tugas dari Majelis Pengawas Daerah (MPD) itu sedniri hanya berhak menyatakan bahwa apakah tindakan dari notaris tersebut dinyatakan salah atau tidaknya, berdasarkan analisis yang saya dapat dan serta putusan yang saya dapat dari Majelis Pengawas Daerah (MPD). bahwa notaris yang saya angkat dalam kasus ini telah dinyatakan bersalah oleh Majelis Pengawas Daerah (MPD).

Lantas mengapa pula di dalam praktek masih banyak sekali kejadian dimana notaris melakukan pelanggaran kode etik atau tidak menaati aturan yang berlaku? Di dalam hal ini sulit dipastikan mengenai apa dan mengapa notaris tersebut melakukan 
hal pelanggaran kode etik tersebut dan ditekankan bahwa setiap notaris memiliki pribadi dan pola pikir yang berbeda-beda, namun mengenai hal ini beliau hanya mengutarakan secara garis besarnya saja, adapun mungkin notaris yang bersangkutan tersebut bekerja sama dengan salah satu ahli waris yang ikut bertanda-tangan di dalam akta tersebut dan mungkin juga ada hal-hal lainnya yang mungkin tidak terfikirkan. $^{18}$

Namun menurut Bu Elli selaku sekretariat Majelis Pengawas Daerah (MPD) didalam kasus ini ada beberapa solusi seperti:

1) Membuat akta pembatalan dengan dihadiri oleh semua ahli waris yang ketika itu menghadap dalam pembuatan akta tersebut.

2) Berdasarkan penetapan pengadilan.

Untuk prosedur pemanggilan notaris ini sendiri harus ada laporan dari pelapor dan juga harus ada bukti-bukti yang cukup kuat seperti dalam kasus ini yang mana pelapor memiliki bukti yang kuat berupa akta keterangan dari notaris terdahulu yang mana nama pelapor ada di dalam akta tersebut sebagai pewaris yang sah dan akta keterangan yang ada saat ini yang tidak memasukkan nama pelapor ke dalam akta tersebut, kemudia setelah data di periksa oleh Majelis Pengawas Daerah (MPD).

nantinya notaris yang bersangkutan beserta pelapor akan di panggil di dalam persidangan dan apabila notaris tersebut dinyatakan bersalah maka dia akan melanjutkan perkara ini ke tingkat Majelis Pengawas Wilayah (MPW) untuk dijatuhkan sanksi apa yang akan dia dapatkan dan setelah itu akan dilanjutkan ke tingkat Majelis Pengawas Pusat (MPP) untuk selanjutnya berwenang untuk memberhentikan notaris yang terbukti bersalah, selanjutnya akan di proses oleh Kementerian Hukum dan Hak Asasi Manusia Republik Indonesia (selanjtnya disebut KEMENKUMHAM). Mentri akan mengeluarkan surat keterangan mengenai surat

\footnotetext{
${ }^{18}$ Peneliti, wawancara, dengan Bapak Aris Hendrawan Halim, (Jakarta: Kantor Notaris dan PPAT, tanggal bulan tahun).
} 
keterangan pemberhentian Notaris yang terbukti bersalah atas dasar putusan yang dikeluarkan oleh MPP. ${ }^{19}$

Mengenai sanksi yang akan dijatuhkan dapat dilihat di Pasal 16 Ayat 11 UndangUndang Jabatan Notaris Nomor 2 Tahun 2014 yang mengatakan:

Notaris yang melanggar ketentuan sebagaimana dimaksud pada Ayat (1) huruf a sampai dengan hurruf 1 dapat dikenakan sanksi berupa:

a) Peringatan tertulis;

b) Pemberhentian sementara;

c) Pemberhentian dengan hormat;

d) Pemberhentian dengan tidak hormat.

Untuk dapat melaksanakan kegiatan pengawasan, maka Majelis Pengawasan Daerah diberikan kewenangan berdasarkan pada ketentuan yang ada yaitu Pasal 70 Undang-undang nomor 30 tahun 2004 tentang jabatan Notaris Jo Pasal 13 ayat (2) dan Menteri. Dapat dilihat pula kewenangan dari Majelis pengawas Daerah sesuai bunyi pada Pasal 70 Undang-undang jabatan Notaris, yaitu sebagai berikut:

Majelis Pengawas Daerah berwenang :

1. Menyelenggarakan sidang untuk memeriksa adanya dugaan pelanggaran kode etik Notaris atau pelanggaran jabatan Notaris;

2. Melakukan pemeriksaan terhadap protocol Notaris secara berkala 1 (satu) kali 1 (satu) tahun atau setiap waktu yang dianggap perlu;

3. Memberikan izin cuti untuk waktu sampai dengan 6 (enam) bulan;

4. Menetapkan Notaris pengganti dengan memperhatikan usul Notaris yang bersangkutan;

5. Menentukan tempat penyimpanan protocol Notaris yang pada saat serah terima protokol Notaris telah berumur 25 (dua ouluh lima) tahun atau lebih.

6. Menunjuk Notaris yang akan bertindak sebagai pemgang sementara protokol Notaris yang diangkat sebagai pejabat Negara sebagaimana dimaksud dalam pasal 11 ayat (4);

7. Menerima laporan dari masyarakat mengenai adanya dugaan pelanggaran ketentuan dalam Undang-undang ini;

\footnotetext{
${ }^{19}$ Peneliti, Wawancara, dengan Ibu Elli Sabarjani, (Jakarta:.........)
} 
8. Membuat dan menyampaikan laporan sebagaimana dimaksud pada angka 1 sampai angka 7 kepada Majelis Pengawas Wilayah.

Sedangkan kewenangan dari Majelis Pengawas Daerah menurut Pasal 13 ayat (4) peraturan Menteri Nomor M.02.PR.08.10 tahun 2004 adalah sebagai berikut :

a. Membrikan izin cuti untuk jangka waktu sampai dengan 6 (enam) bulan;

b. Menetapkan Notaris pengganti

c. Menentukan tempat penyimpanan protokol Notaris yang pada saat serah terima protokol Notaris telah berumur 25 (dua puluh lima) tahun atau lebih;

d. Menerima laporan dari masyarakat mengenai adanya dugaan pelanggaran.

Memberi paraf dan menandatangani daftar akta, daftar surat di bawah tangan yang disahkan, dan daftar surat di bawah tangan yang dibukukan yang telah disahkan, yang dibuat pada bulan sebelumnya paling lambat 15 (lima belas) hari kalender pada bulan berikutnya, yang memuat sekurang-kurangnya nomor, tanggal dan judul akta.

Terkait kasus yang bersangkutan hanya baru sampai kepada tingkat Majelis Pengawas Daerah (MPD) saja, dan sudah diserahkan kepada tingkatan selanjutnya mengenai sanksi apa yang akan dijatuhkan yaitu tingkat Majelis Pengawas Wilayah (MPW), setelah diketahui sanksi apa yang akan dijatuhkan maka akan diserahkan mengenai pelaksaan sanksi tersebut oleh tingkat selanjutnya yaitu tingkat Majelis Pengawas Pusat (MPP).

\section{PENUTUP}

\section{A. Kesimpulan}

Pada bab V ini penulis akan mengemukakan hasil dari penelitian di atas dengan memberikan kesimpulan dari permasalahn yang terdapat dalam skripsi yang berjudul "Penerapan Kode Etik Notaris dalam Pembuatan Akta Pembagian Hak Waris No 31 Menurut UUJN No 2 Tahun 2014”. Dalam hal ini penulis mengambil sebuah kesimpulan bahwa pada dasarnya suatu aturan itu dibuat untuk ditaati dan dijalankan 
sebaik-baiknya terutama bagi pengemban profesi notaris yang mana sebelum menjadi notaris terlebih dahulu melakukan sumpah jabatan notaris.

\section{B. Saran}

Dari kesimpulan tersebut di atas, maka dalam kesempatan ini penulis ingin memberikan sedikit saran dalam penyelesaian permasalahan ini: Adapun sebuah profesi yang diemban pasti memiliki tanggung jawabnya sendiri-sendiri, agar proses tersebut berjalan dengan lebih baik alangkah sebaiknya dilakukan proses penyeleksian atau penyaringan lebih di perketat dalam hal syarat dan ketentuan yang harus dimiliki untuk dapat menjabat suatu jabatan.

\section{DAFTAR PUSTAKA}

HS, H Salim. Teknik Pembuatan Akta Satu. Jakarta: Raja Grafindo Persada, 2015.

Kie, Tan Thong. Studi Notariat serba-serbi praktek notaris. Jakarta: PT Ichtiar Baru Van Hoeve, 2007.

Marzuki, Peter Mahmud. Penelitian Huku. Jakarta: Kencana, 2006.

Muhammad, Abdulkadir. Etika Profesi Hukum. Bandung: PT Citra Aditya Bakti.

Naja, Daeng. Teknik Pembuatan Akta. Yogyakarta: Pustaka Yustisia, 2012.

ND, Mukti Fajar dan Yulianto Achmad. Dualisme Penelitian Hukum Normatif dan Empiris. Yogyakarta: Pustaka Belajar, 2010.

Soekanto, Soerjono. Pengantar Penelitian Hukum. jakarta: UI Press, 1986.

Soekanto, Soerjono dan Sri Mamudji. Penelitian Hukum Normatif Suatu Tinjauan Singkat. Jakarta: PT Raja Grafindo Persada 2009.

Subekti, R. Hukum Pembuktian. Jakarta: Pradnya Paramita, 1995.

Supriadi, Etika dan Tanggung Jawab Profesi Hukum di Indonesi., Jakarta: Sinar Grafika, 2006.

Indonesia. Undang-undang Nomor 2 Tahun 2014 tentang Jabatan Notaris (Lembaran Negara Republik Indonesia Tahun 2014 Nomor 3, Tambahan Lembaran Negara Republik Indonesia Nomor 5491). 